Sains Malaysiana 49(9)(2020): 2187-2196

http://dx.doi.org/10.17576/jsm-2020-4909-16

\title{
Effects of a Newly Developed Palm-Based Processing Aid and Curing Systems on the Physical Properties of Nitrile Rubber Composites
}

(Kesan Pembangunan Baharu Bantuan Pemprosesan Berasaskan Sawit dan Sistem Pemvulkanan pada Sifat Fizikal Komposit Getah Nitril)

\author{
Hani Mohd HaniF*, KoK ChOng Yong \& SiAng Yin LeE
}

\begin{abstract}
Researches on developing renewable and eco-friendly processing aid are still on-going in the effort of replacing conventional petroleum-based processing aid. In this study, the effects of a palm-based processing aid (Bio) and curing systems on the physical properties of nitrile rubber (NBR) composites were evaluated. Curing systems studied were conventional (CV), semi-efficient (SEV) and efficient (EV) curing systems. It was found that regardless of the curing systems, the addition of Bio reduced the delta torque, cure rate index, glass transition temperature and loss tangent of the NBR composites. Reduction of delta torque by Bio resulted in lower tensile modulus (M100) and higher elongation at break (EB) of composites. Hardness, swelling index and compression set were also higher with the incorporation of Bio. The effects of curing system were also prominent in which using CV cure system leads to higher M100 and hardness and lower EB and compression sets. Excellent aging properties are crucial as it predicts the properties of the composite during service. After accelerated aging, results revealed that the effects of curing systems were significant on the retention of M100 and compression set of NBR composites where the SEV cured composites showed the highest retention of 100 and the lower compression set values. NBR composite with Bio, using a semi-efficient curing system was found to have the best aging properties compared to other composites.
\end{abstract}

Keywords: Bio-based; curing system; nitrile rubber; physical properties; processing aid

\section{ABSTRAK}

Penyelidikan untuk membangunkan bantuan pemprosesan yang mapan dan mesra alam masih berterusan dalam usaha menggantikan bantuan pemprosesan konvensional berasaskan petroleum. Dalam kajian ini, kesan sistem pemprosesan berasaskan sawit (Bio) dan sistem pemvulkanan pada sifat fizikal komposit getah nitril (NBR) dinilai. Sistem pemvulkanan yang dikaji adalah sistem pemvulkanan konvensional (CV), separa cekap (SEV) dan cekap (EV). Tanpa mengira sistem pemvulkanan, penambahan Bio mengurangkan tork delta, indeks kadar pemvulkanan, suhu peralihan kaca dan kehilangan tangen komposit NBR. Pengurangan tork delta oleh Bio menghasilkan modulus tegangan (M100) yang rendah dan pemanjangan pada patahan (EB) yang lebih tinggi pada komposit. Kekerasan, indeks pembekakan dan set mampatan juga lebih tinggi dengan penggunaan Bio. Kesan sistem pemvulkanan juga ketara dengan menggunakan sistem pemvulkanan CV membawa kepada M100 dan kekerasan yang lebih tinggi dan EB serta set mampatan yang lebih rendah. Sifat penuaan yang sangat baik adalah penting kerana ia meramalkan ciri-ciri komposit semasa perkhidmatan. Selepas penuaan dipercepatkan, hasil menunjukkan bahawa kesan sistem pemvulkanan adalah ketara pada pengekalan M100 dan set mampatan komposit NBR dengan komposit SEV menunjukkan pengekalan M100 tertinggi dan nilai set mampatan lebih rendah. NBR komposit dengan Bio, menggunakan sistem pengawetan separa cekap didapati mempunyai sifat penuaan terbaik berbanding komposit lain.

Kata kunci: Bantuan pemprosesan; berasaskan Bio; getah nitril; pemvulkanan; sifat fizikal

\section{INTRODUCTION}

In rubber compounding, processing aid is used to reduce the viscosity of rubber and help in dispersing fillers for a better mixing process. Currently, petroleum-based process oils such as paraffinic, naphthenic, and aromatic oil are widely used as rubber processing aid due to their good compatibility with rubbers (Siwarote et al. 2017). Nonetheless, this type of processing aid was found to be harmful to humans and the environment due to the high content of polycyclic aromatic hydrocarbons (PAHs) which are classified as carcinogenic (Siwarote et al. 2017). Rising awareness on the use of these chemicals has led to the implementation of more stringent rules and regulations such as the Registration, Evaluation, Authorisation and Restriction of Chemicals (REACH) which pertains the limits of the toxic chemicals in rubber goods. Therefore, 
due to the environmental and sustainability concerns, alternatives to petroleum-based process oil as rubber processing aid are being explored and developed.

Processing aid can be derived from vegetable oil to replace the conventional process oil as it is sustainable, low cost and non-toxic. Previous researches have studied the efficacy of some common vegetable oils such as soybean oil (Li et al. 2016; Petrović et al. 2017, 2013; Wang et al. 2013), rubber seed oil (Nandanan et al. 1999) and castor oil (Indrajati \& Dewi 2017; Pechurai et al. 2015; Raju et al. 2007) as an extender or processing aid in rubber compounding. Palm oil is one of the most abundant oils in Malaysia which has also been studied for the same purpose (Jayewardhana et al. 2009; Siwarote et al. 2017; Wang et al. 2016). The introduction of palm oil as plasticizer has improved the processability of rubber during mixing by reducing its Mooney viscosity (Siwarote et al. 2017; Wang et al. 2016). Palm oil also has one of the best heat resistance compared to other vegetable oils (Jayewardhana et al. 2009) which is useful for high-temperature application. However, Wang et al. (2016) found that higher doses of palm oil ( $>40 \mathrm{phr}$ ) reduced the crosslink density of the rubber composite, resulting in undesired mechanical properties. In another study, at a much lower dosage ( $5 \mathrm{phr}$ ), the use of palm oil showed higher abrasion mass loss and higher compression set compared to when using naphthenic, sunflower, and soybean oils as processing aids (Jayewardhana et al. 2009). These findings show that further studies and improvements on palm oil as a rubber processing aid is still necessary.

Vulcanization system of rubber determines the types of crosslink network and crosslink density in a composite. Depending on the sulfur/accelerator ratio, sulfur curing systems can be categorized into conventional (CV), semi-efficient (SEV) and efficient (EV) curing systems. The CV curing system has higher sulfur ratio than accelerator which will result in mostly polysulfidic crosslinks (Kinasih \& Fathurrohman 2017). In contrast, the EV curing system has higher accelerator ratio than sulfur which will produce mainly monosulfidic crosslinks (Kinasih \& Fathurrohman 2017). The SEV curing system has an intermediate level of sulfur and accelerator, contains a higher amount of di- and polysulfidic than monosulfidic crosslinks (Kinasih \& Fathurrohman 2017). The differences in types of crosslink network and crosslink density will significantly affect the processing and properties of a product hence, the type of vulcanization system must be carefully selected.

In this study, the effects of an in-house synthesis processing aid based on palm oil derivative (Bio) and curing systems on carbon black-filled nitrile rubber (NBR) composites were investigated. Three types of curing systems were used which are $\mathrm{CV}, \mathrm{EV}$ and SEV curing systems. Tensile properties, hardness, compression set, accelerated aging properties are among important properties evaluated to optimize the formulation.

\section{MATERIALS AND METHODS}

\section{SYNTHESIS AND CHARACTERIZATION OF PALM-BASED PROCESSING AID}

The green and bio-compatible palm oil-based processing aid (Bio) is a type of polyester, synthesized using synthesis route as reported elsewhere (Lee 2018). Bio was subjected to Fourier transform infrared (FTIR) spectroscopic analysis using a Thermo Scientific FTIR Nicolet 6700 series FTIR spectrometer. FTIR spectrum was recorded with 32 scans ranged from 4000 to $600 \mathrm{~cm}^{-1}$ with the resolution of $2 \mathrm{~cm}^{-1}$ at ambient temperature. Differential scanning calorimetry (DSC) analysis was performed using a Mettler Toledo DSC 1. Cyclohexane was used for temperature calibration and data was analysed using STARe SW 13.00 software. Thermogravimetric analysis (TGA) was carried out using a Perkin Elmer Thermal Analyzer (STA) 6000. The measurement was carried out from 30 to $850{ }^{\circ} \mathrm{C}$ with a heating rate of $20^{\circ} \mathrm{C} / \mathrm{min}$ under a nitrogen atmosphere. Data analysis was performed using Pyris software. A Malvern GPC Viscotek gel permeation chromatography (GPC) instrument was operated with organic GPC/ SEC columns. The flow rate of $0.8 \mathrm{~mL} / \mathrm{min}$, and using $3 \times$ CLM3005-T5000 were employed in the system. Calibration was performed using polyisoprene standards. Result of number-average molecular weight $(\mathrm{Mn})$ was recorded.

\section{MATERIALS}

Nitrile butadiene rubber (NBR), DN 3350 used was produced by Zeon Chemicals. Fast extrusion furnace (FEF) carbon black filler grade N550 was obtained from Cabot (M) Sdn. Bhd. Sulfur and activators such as zinc oxide and stearic acid were from Centre West Sdn. Bhd. Calcium stearate and an antioxidant, 2,2,4-trimethyl1,2-dihydroquinoline (TMQ) were bought from Galin Enterprise. Accelerators such as tetramethyl thiuram disulphide (TMTD) and N-tert-butyl-2-benzothiazole sulfenamide (TBBS) were from Galin Enterprise and Luxchem Trading, respectively.

\section{COMPOUNDING}

All ingredients as listed in Table 1 were mixed with a two-roll mill at room temperature. The cure characteristics such as cure time $\left(\mathrm{T}_{90}\right)$, scorch time $\left(\mathrm{T}_{\mathrm{S} 2}\right)$, minimum torque $\left(\mathrm{M}_{\mathrm{L}}\right)$ and maximum torque, $\left(\mathrm{M}_{\mathrm{H}}\right)$ of the rubber compounds were obtained using a Monsanto Rheometer (MDR 2000) at $150{ }^{\circ} \mathrm{C}$ for $30 \mathrm{~min}$. Cure rate index was calculated using (1):

$$
\text { Cure rate index }(C R I)=\frac{100}{\left(T_{90}-T_{S 2}\right)}
$$


The rubber compounds were cured based on their respective $\left(\mathrm{T}_{90}\right)$ at $150{ }^{\circ} \mathrm{C}$ using a hot press machine.

\section{MEASUREMENTS}

Dynamic mechanical analysis was performed using a Mettler Toledo Dynamic Mechanical Analyser (DMA1 Start system) using temperatures from -100 to $+100{ }^{\circ} \mathrm{C}$ in tension mode at $10 \mathrm{~Hz}, 0.1 \%$ strain in accordance with ISO 4664-1. Tensile test was carried out according to BS ISO 37 at a constant cross-head rate of $500 \mathrm{~mm} / \mathrm{min}$ using an Instron universal testing machine. At least five dumbbell specimens were cut from vulcanized rubber slabs and conditioned at room temperature before testing. Hardness was measured following ISO 48. To obtain the compression set of the composites, rubber cylindrical samples $(6 \times 13 \mathrm{~mm})$ were put under $25 \%$ constant compression for $24 \mathrm{~h}$ at room temperature and $70{ }^{\circ} \mathrm{C}$. The percentage of compression sets were calculated using (2) as follows:

Compression set $(\%)=\frac{\text { original thickness-Recovered thickness }}{\text { Original thickness-Spacer thickness }} \times 100 \%$

Swelling test was carried out following the ISO 1817 where the vulcanizates were immersed in toluene for three days at room temperature. Swelling index is calculated using (3) as follows:

Swelling index $(\%)=\frac{\text { Weight of swollen rubber-Weight of unswollen rubber }}{\text { Weight of unswollen rubber }} \times 100 \%$

Aging test was carried out by exposing tensile and hardness specimens to air temperature of $100{ }^{\circ} \mathrm{C}$ in an oven for $70 \mathrm{~h}$. The percentage of retention (\%) of tensile properties and hardness were calculated using (4) as follows:

$$
\text { Retention }(\%)=\frac{\text { Aged property }}{\text { Unaged property }} \times 100 \%
$$

\section{RESULTS AND DISCUSSION}

\section{CHARACTERIZATION OF PROCESSING AID}

The palm-based processing aid (Bio) has a semisolid appearance at room temperature with a glass transition temperature $\left(T_{g}\right)$ of $31.9{ }^{\circ} \mathrm{C}$ as measured from DSC. The molecular weight of the processing aid obtained from GPC was $972 \mathrm{~g} / \mathrm{mol}$. TGA result shows that Bio has high thermal stability above $200{ }^{\circ} \mathrm{C}$ with the majority of weight loss accounted for about $46.2 \%$ at $339^{\circ} \mathrm{C}$. Figure 1 shows the FTIR spectrum of Bio. The $-\mathrm{C}=\mathrm{O}$ stretching found at $1742-1737 \mathrm{~cm}^{-1}$ corresponds to ester linkages. The $-\mathrm{OH}$ stretching appears as a broad absorption band at $3498-3440 \mathrm{~cm}^{-1}$, C-H stretching of methane group appears at $2949-2921 \mathrm{~cm}^{-1}$, C-H stretching of methylene group appears at 2852-2849 $\mathrm{cm}^{-1}$, C-H bending of methylene group appears at 1467-1377 $\mathrm{cm}^{-1}$, C-O-C stretching appears at 1237-1012 $\mathrm{cm}^{-1}$ and lastly $\mathrm{C}-\mathrm{H}$ out-of-plane stretching appears at $722-720 \mathrm{~cm}^{-1}$. The proposed chemical structure of Bio was displayed in Figure 2. These properties, especially the functional group will determine the compatibility and efficiency of the processing aid.

\section{CURE CHARACTERISTICS}

Cure characteristics of composites provide information on the properties and processing of the compounds. Table 2 shows the effects of curing systems and processing aid on the cure characteristics of NBR compounds obtained from a rheometer. Firstly, it can be seen that the addition of processing aid reduced the delta torque of the composites. Delta torque is the difference between the minimum and maximum torque and indirectly indicates the crosslink density of a composite. The reduction in crosslink density could be due to the softening or lubricating effects of processing aid which could produce boundary layers which coat and absorb sulfur and filler and eventually, less sulfur and filler are available to form crosslinks with the rubber chain (Surya et al. 2013). It can also be observed from Table 2 that the delta torque of NBR composites was found to be the highest with CV cure system. The high amount of sulfur available for the crosslinks formation in CV cure system had contributed to the high delta torque value compared to other cure systems (Ismail et al. 1997; Rattanasom et al. 2005). Besides that, the incorporation of Bio also lengthens the cure and scorch time which result in lower cure rate index. The effect of Bio on scorch and cure time are highly significant with SEV system, in which the CRI dropped from 90.9 to $42.9 \mathrm{~min}^{-1}$. Nonetheless, the CRI of all BioNBR composites were close to each other (42.9 - 48.8 $\mathrm{min}^{-1}$ ). These findings show that Bio causes a retardation effect on the curing of the compounds. Similarly, a study had shown that palm oil fatty acid behaves like retarders which are contributed by the complex formation of chelates between zinc ion from stearic acid and the accelerator, intermediate reaction products or crosslink precursors (Ismail et al. 1997).

\section{SWELLING INDEX}

Swelling index indicates the crosslink density of the composite. Table 3 displays the swelling index of NBR composites produced in this study. Highly crosslinked material will have a lower swelling index as these crosslinks restrict the extensibility of rubber chains caused by swelling thus makes it difficult for the solvent to penetrate the rubber network (Alam et al. 2003; Mostafa et al. 2009). In this study, it can be seen from Table 3 that the swelling index of NBR composites with EV cure system was the highest whereas NBR composites with SEV and CV cure systems had similar swelling values. These results have a high correlation with delta 
torque values where EV cured NBR composites also showed the lowest delta torque values i.e. crosslink density compared to $\mathrm{CV}$ and SEV cured composites. Besides that, NBR composite with CV cure system without any processing aid had the lowest swelling index which is in line with their highest delta torque values obtained from the rheometer.

\section{DYNAMIC MECHANICAL ANALYSIS}

Figure 3 displays the loss tangent curves of NBR composites. Loss tangent curve provides information on the glass transition temperature $\left(T_{g}\right)$, processing and damping properties of a composite. $T_{g}$ is usually referred to as the temperature of the loss tangent peak. As displayed in Figure 3, the $T_{g}$ of composites were significantly different from each other depending on the type of curing system. NBR composites with EV cure system recorded $T_{g}$ around $-12{ }^{\circ} \mathrm{C}$ whereas composites with SEV and CV cure systems had $T_{\text {a }}$ around $-8{ }^{\circ} \mathrm{C}$. The difference in $T_{g}$ could be due to the difference in crosslink density. Lower crosslink density requires a lower amount of energy for the segmental motion of the rubber chain hence, lower $T_{g}$. The performance of Bio as processing aid can also be determined by looking at the change in $T_{g}$. The addition of Bio into the formulation slightly lowers the $T_{g}$ from -11.8 to $-12.6{ }^{\circ} \mathrm{C}$ and -7.6 to $-8.6^{\circ} \mathrm{C}$ with EV and SEV cure systems, respectively. The $T_{g}$ of composites with $\mathrm{CV}$ cure system shows similar $T_{g}$ at $-8{ }^{\circ} \mathrm{C}$. The slight reduction in $T_{g}$ indicates an improvement in the processability of the rubber. Processing aid lowers the $T_{g}$ as it provides a free volume, allowing more flexibility for the rubber chains to move (Surya et al. 2015). Loss tangent $(\tan \delta$ ) is essentially a ratio of viscous over the elastic component. Based on Figure 3, it can be said that the addition of Bio reduced the $\tan \delta$ of the composites from 1.3 to 1.1 . The reduction of $\tan \delta$ could be due to micro-plasticization of rubber-filler by processing aid which reduces the amount of heat generated as a result of shearing at the rubberfiller interface (Kundu 2000). This leads to better filler dispersion and rubber-filler interaction (Kundu 2000) hence, indicate better processability of rubber.

\section{TENSILE PROPERTIES}

Tensile properties are usually used in many studies as a comparative tool to evaluate a composite. In this study, tensile properties are expressed in terms of tensile strength, elongation at break and tensile modulus (M100) and are exhibited in Figure 4. It can be seen that the EV cure system resulted in the lowest M100 whereas the SEV and CV had similar M100 values. Lower M100 values were recorded with Bio-NBR composites regardless of curing systems. Result of M100 exhibits a similar trend with delta torque and swelling test. This is because these properties are highly influenced by the crosslink density of the composites. Elongation at break (EB) of NBR composites were significantly different from each other and was the highest with EV system since the M100 i.e. stiffness was the lowest. The effect of processing aid is also prominent since NBR composites with Bio exhibit higher EB compared to NBR composites without Bio. The tensile strength of the composites from the highest to the lowest are as follows, $\mathrm{CV}>\mathrm{EV}>\mathrm{SEV}$. Tensile strength shows a different trend compared to M100 and EB. There are no significant effects of processing aid and curing systems on the tensile strength of these composites.

\section{HARDNESS}

Hardness measures the resistance of composites to indentation or deformation. The hardness of NBR composites is tabulated in Table 4. It is apparent that the hardness of NBR composite cured with CV system had the highest hardness values, followed by SEV and EV cure system. These results indicate that there are more crosslinks formed in the $\mathrm{CV}$ system due to the higher amount of available sulfur for crosslink formation compared to SEV and EV systems (Rattanasom et al. 2005). The hardness of the composites increased with the addition of Bio regardless of the type of curing system. The increase in hardness could be contributed to the structure of processing aid i.e. types of functional groups, which can form considerable branching and chaining with rubber hence, influencing the crosslinking (Rahmah et al. 2013).

\section{COMPRESSION SETS}

Figure 5 shows the effects of processing aid and curing systems on the compression sets of NBR composites. Generally, the lower the compression set, the higher the elastomeric property of the composite. From Figure 5, the compression set increased with the addition of processing aid. EV cured composites show the highest compression values followed by SEV and CV cured composites with and without Bio. This phenomenon is due to the lowest sulfur loading in the EV cure system compared to the others. A higher amount of sulfur will increase the crosslinks in the rubber (Rattanasom et al. 2005) hence, a higher elastomeric property of the composite. The higher compression set of Bio-NBR composites is also due to the reduction in crosslink density by Bio.

\section{AGING PROPERTIES}

The effects of curing systems with and without Bio on thermal aging resistance of the vulcanizates were also investigated. This is important as protection from heat can extend the service life of rubber goods (Komethi et al. 2012). Table 5 shows the retention percentage of tensile properties and hardness of aged vulcanizates. It can be seen that the retention percentage of hardness and M100 of NBR composites exceeded $100 \%$. This is because 
crosslinking reaction dominates during aging of NBR i.e. increase in crosslink density results in stiffening of composites (Liu et al. 2016). Since the crosslink density increases, the relative movement of network chains decreases (Liu et al. 2016). As a result, the retention of elongation at break was only in the range of $54-66 \%$ as depicted in Table 5. Aged NBR composites show no conclusive trend on the retention percentage of tensile strength.

The effect of curing systems on NBR composites was more pronounced on M100. It can be observed that composites with SEV cure system at $0 \mathrm{phr}$ processing aid had the highest retention of M100 values (180\%) followed by EV (161\%) and CV (157\%) cure systems. This is attributed to the better heat stability of mono- and di-sulfidic networks in SEV and EV vulcanizates than the polysulfidic network in CV cured NBR composite (Rattanasom et al. 2005). With the addition of Bio, the retention of M100 was either similar (SEV) or higher (EV and CV) than without any processing aid. This is probably attributed to the more available sulfur or accelerator that are not used during curing hence, higher crosslinking during aging. Another possible reason is due to better compatibility of aged NBR with Bio. It was reported that oxygenated species such as hydroxyl and carbonyl groups were formed for aged NBR (Liu et al. 2016).
Therefore, Bio may forms hydrogen bonds with the oxygenated species in the rubber chains as it also contains polar groups such as carbonyl and hydroxyl groups in its structure hence, contributes to the higher crosslink density of the composites after thermal aging.

Compression sets of aged NBR composites with different curing systems and concentration of Bio are displayed in Figure 6. The compression sets of $\mathrm{CV}$ cured NBR composites were the highest compared to EV and SEV cured composites regardless of the presence of Bio. This is because polysulfidic linkages that form dominantly in $\mathrm{CV}$ cure system have the least thermal stability compared to mono- and di-sulfidic networks in SEV and EV vulcanizates (Rattanasom et al. 2005). It can also be observed that SEV cured Bio-NBR composite recorded the lowest compression set, better than EV cured composites. This could be due to the higher crosslink density as indicated by retention of M100 and the formation of higher di-sulfidic linkages in SEV compared to EV curing system that could expand the rubber chain between two successive crosslink points hence, the mobility of chain was not entangled (Nabil et al. 2014). Since the stiffness of aged SEV cured composites are similar, the improvement in compression set by Bio could be due to the compatibility of Bio with aged NBR composite.

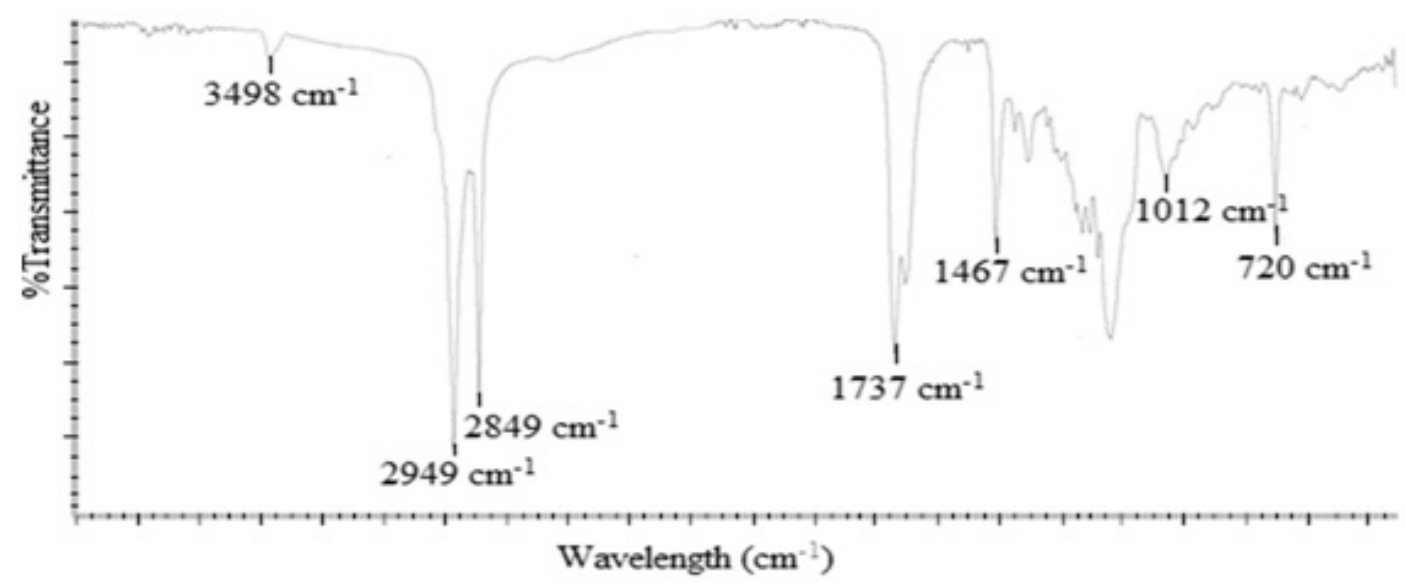

FIGURE 1. FTIR spectra of palm-based processing aid, Bio

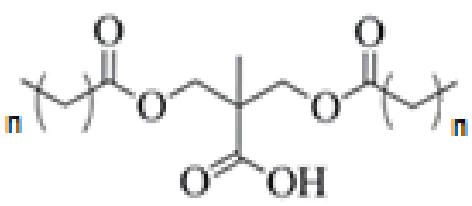

FIGURE 2. A proposed chemical structure of Bio 


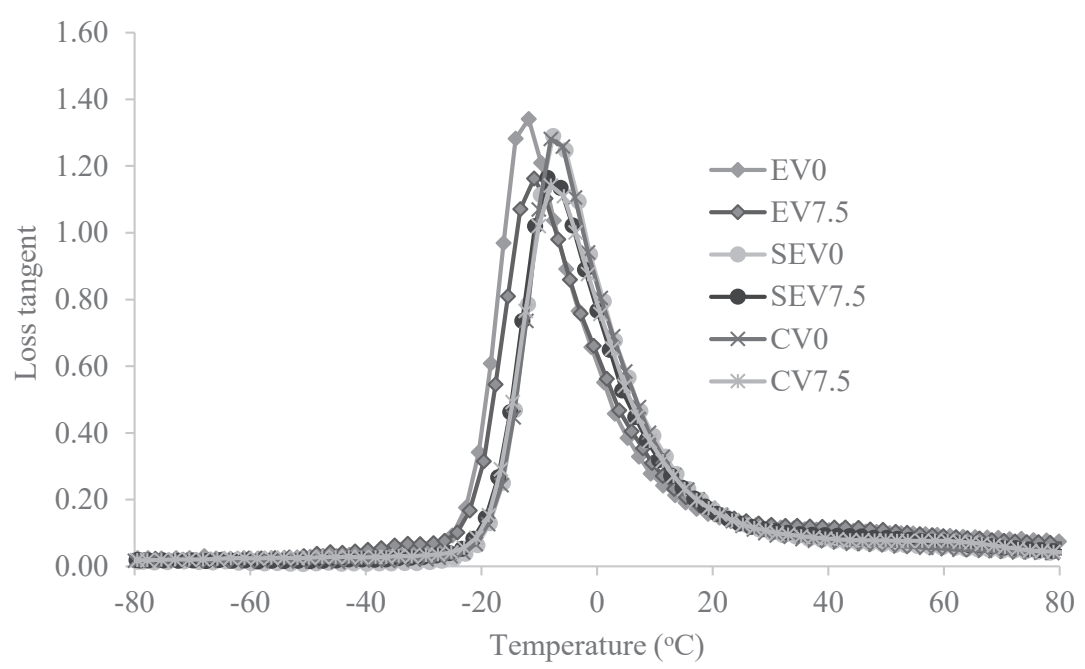

FIGURE 3. Loss tangent curves of NBR composites

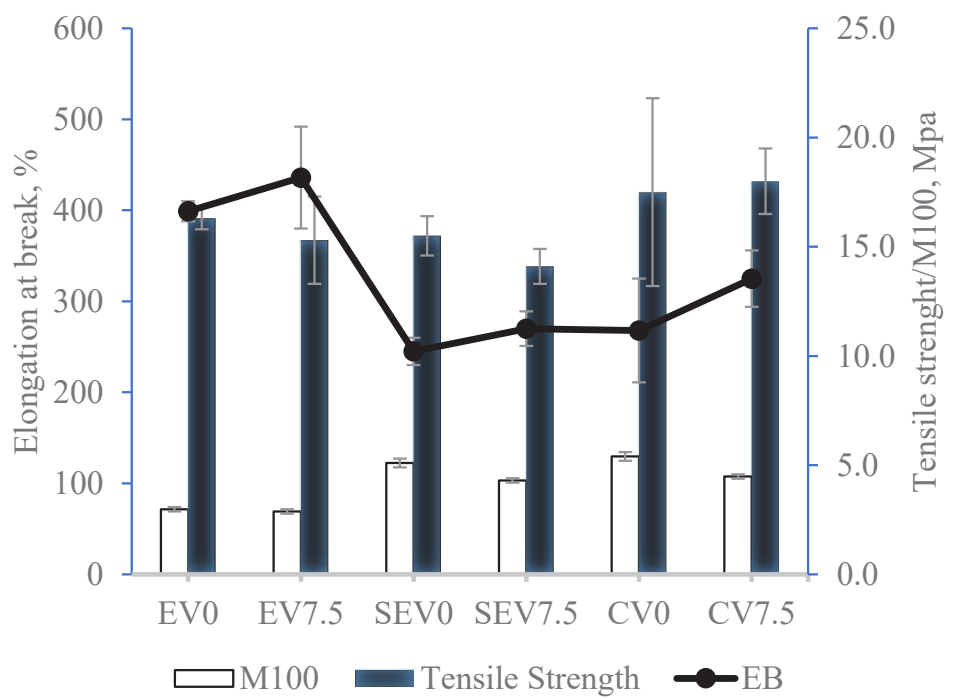

FIGURE 4. Tensile properties of NBR composites

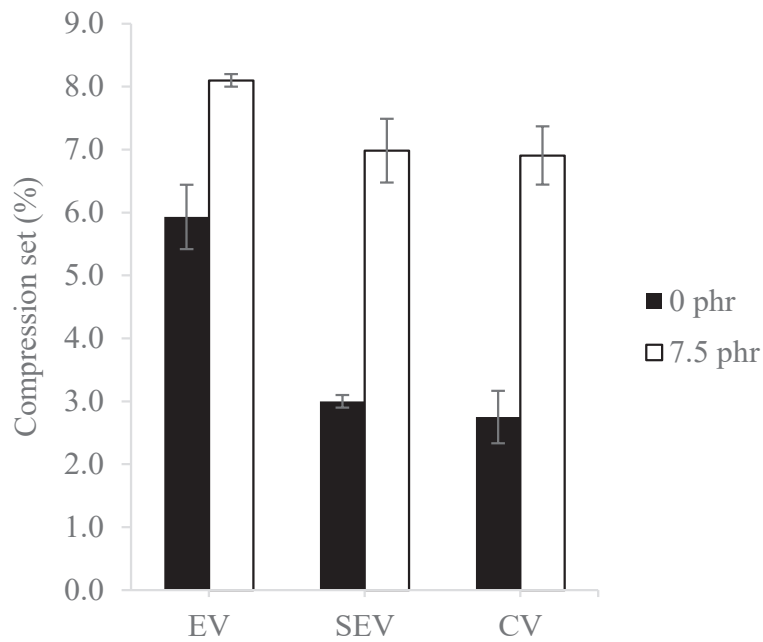

FIGURE 5. Compression sets of EV, SEV and CV cured NBR composites 


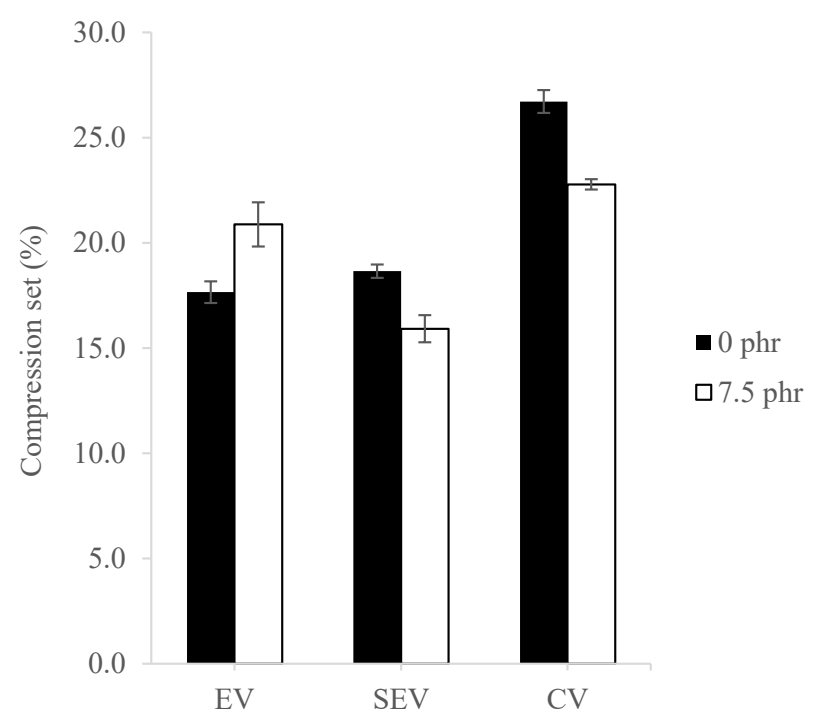

FIGURE 6. Compression sets of aged NBR composites

TABLE 1. Compounding formulations

\begin{tabular}{|c|c|c|c|c|c|c|}
\hline Ingredients & EV0 & EV7.5 & SEV0 & SEV7.5 & CV0 & CV7.5 \\
\hline NBR, Nipol DN3350 & 100.0 & 100.0 & 100.0 & 100.0 & 100.0 & 100.0 \\
\hline Black FEF, N 550 & 40.0 & 40.0 & 40.0 & 40.0 & 40.0 & 40.0 \\
\hline Zinc Oxide & 5.0 & 5.0 & 5.0 & 5.0 & 5.0 & 5.0 \\
\hline Stearic Acid & 2.0 & 2.0 & 2.0 & 2.0 & 2.0 & 2.0 \\
\hline Calcium stearate & 2.0 & 2.0 & 2.0 & 2.0 & 2.0 & 2.0 \\
\hline TMQ & 2.0 & 2.0 & 2.0 & 2.0 & 2.0 & 2.0 \\
\hline Bio & 0.0 & 7.5 & 0.0 & 7.5 & 0.0 & 7.5 \\
\hline Sulfur & 0.8 & 0.8 & 2.5 & 2.5 & 3.5 & 3.5 \\
\hline TMTD & 1.4 & 1.4 & 1.0 & 1.0 & 0.4 & 0.4 \\
\hline TBBS & 1.4 & 1.4 & 1.0 & 1.0 & 0.4 & 0.4 \\
\hline
\end{tabular}

TABLE 2. Cure characteristics of NBR composites

\begin{tabular}{ccccccc}
\hline Properties & EV0 & EV7.5 & SEV0 & SEV7.5 & CV0 & CV7.5 \\
\hline $\mathrm{M}_{\mathrm{L}}, \mathrm{dNm}$ & 1.2 & 1.1 & 1.3 & 1.0 & 1.3 & 1.2 \\
$\mathrm{M}_{\mathrm{H}}, \mathrm{dNm}$ & 20.5 & 18.5 & 28.9 & 25.7 & 30.7 & 27.2 \\
$\begin{array}{c}\text { Delta torque, } \\
\mathrm{dNm}\end{array}$ & 19.3 & 17.4 & 27.6 & 24.7 & 29.4 & 26.0 \\
$\mathrm{~T}_{\mathrm{S} 2}, \mathrm{~min}$ & 1.4 & 1.9 & 1.6 & 1.4 & 1.2 & 1.5 \\
$\mathrm{~T}_{90}, \mathrm{~min}^{-1}$ & 3.0 & 4.0 & 2.3 & 3.8 & 3.2 & 3.5 \\
$\mathrm{CRI}, \mathrm{min}^{-1}$ & 63.3 & 46.9 & 90.9 & 42.9 & 50.8 & 48.8 \\
\hline
\end{tabular}


TABLE 3. Swelling index of composites

\begin{tabular}{ccc}
\hline & \multicolumn{2}{c}{ Swelling index (\%) } \\
\cline { 2 - 3 } Cure system/Processing aid & $0 \mathrm{phr}$ & $7.5 \mathrm{phr}$ \\
\hline EV & $107.1 \pm 0.6$ & $111.9 \pm 1.0$ \\
SEV & $87.6 \pm 0.6$ & $76.7 \pm 1.2$ \\
CV & $76.0 \pm 1.0$ & $76.9 \pm 1.5$ \\
\hline
\end{tabular}

TABLE 4. Hardness of NBR composites

\begin{tabular}{ccc}
\hline & \multicolumn{2}{c}{ Hardness (IRHD) } \\
\cline { 2 - 3 } Cure system/Processing aid & $0 \mathrm{phr}$ & $7.5 \mathrm{phr}$ \\
\hline EV & $69.4 \pm 0.3$ & $72.5 \pm 0.1$ \\
SEV & $76.9 \pm 0.1$ & $77.1 \pm 0.1$ \\
CV & $77.8 \pm 0.4$ & $78.9 \pm 0.1$ \\
\hline
\end{tabular}

TABLE 5. Retention of hardness and tensile properties of aged NBR composites

\begin{tabular}{ccccccc}
\hline Properties & EV0 & EV7.5 & SEV0 & SEV7.5 & CV0 & CV7.5 \\
\hline Retention of tensile strength (\%) & 89 & 101 & 97 & 99 & 101 & 88 \\
Retention of elongation at break (\%) & 56 & 60 & 59 & 60 & 66 & 54 \\
Retention of M100 (\%) & 161 & 167 & 180 & 179 & 157 & 172 \\
Retention of hardness (\%) & 110 & 108 & 106 & 107 & 105 & 106 \\
\hline
\end{tabular}

\section{CONCLUSION}

The effects of an in house-synthesis palm-based processing aid, Bio, and curing systems on NBR composites were studied. It was found that the use of Bio shows improvement in processability as $T_{g}$ and $\tan \delta$ were reduced. Regardless of curing systems, the addition of Bio retards vulcanization process which is particularly useful in manufacturing extruded products. The finding of this study also shows that Bio reduced the crosslink density of the composites whereas using a CV curing system increased the crosslink density as observed by the delta torque and swelling index. The higher crosslink density of $\mathrm{CV}$ vulcanizates resulted in higher $T_{g}, \mathrm{M} 100$ and hardness whereas the elongation at break and compression sets were lower compared to EV and SEV cured NBR composites. No significant difference in terms of the tensile strength of NBR composites can be observed. After accelerated aging, stiffening of all NBR 
composites can be seen by the increase in compression set, retention of hardness and M100 and by the reduction in the retention of elongation at break. Effect of curing systems was significant on the retention of M100 and compression set where the SEV cured composites recorded the highest retention percentage of M100 and lower compression set values. SEV cured Bio-NBR composite was found to have the best aging resistance compared to other composites. The findings of this study could contribute to the development of a more sustainable and eco-friendly material with excellent aging resistance for various applications such as in the automotive industry as it may offer longer shelf-life during service.

\section{ACKNOWLEDGEMENTS}

This work was supported by the Malaysian Rubber Board. Assistances given by Mr Hasrol, Mr Hassanal and Mr Meor throughout the project are highly appreciated.

\section{REFERENCES}

Alam, M.M., Mina, M.F. \& Akhtar, F. 2003. Swelling and hydration properties of acrylamide hydrogel in distilled water. Polymer - Plastics Technology and Engineering 42(4): 533-542.

Indrajati, I.N. \& Dewi, I.R. 2017. Performance of maleated castor oil based plasticizer on rubber: Rheology and curing characteristic studies. In IOP Conference Series: Materials Science and Engineering. Medan, Indonesia. p. 012001.

Ismail, H., Salmiah, I. \& Tsukahara, Y. 1997. Palm oil fatty acid as an activator in carbon black filled natural rubber compounds: Effect of vulcanization system. Polymer International 44(4): 523-529.

Jayewardhana, W.G.D., Perera, G.M., Edirisinghe, D.G. \& Karunanayake. L. 2009. Study on natural oils as alternative processing aids and activators in carbon black filled natural rubber. Journal of the National Science Foundation of Sri Lanka 37(3): 187-193.

Kinasih, N.A. \& Fathurrohman, M.I. 2017. Effects of curing systems on mechanical properties and N-pentane resistance of carbon black filled natural rubber vulcanizates. Journal of Engineering and Science Research 1(2): 245-251.

Komethi, M., Othman, N., Ismail, H. \& Sasidharan, S. 2012. Comparative study on natural antioxidant as an aging retardant for natural rubber vulcanizates. Journal of Applied Polymer Science 124(2): 1490-1500.

Kundu, P.P. 2000. Improvement of filler-rubber interaction by the coupling action of vegetable oil in carbon black reinforced rubber. Journal of Applied Polymer Science 75(6): 735-739.

Lee, S.Y. 2018. Palm based polymeric surfactants for improved latex film formation. In 9th Internal Rubber Glove Conference and Exhibition (IRGCE), Kuala Lumpur Convention Centre (KLCC). Kuala Lumpur, Malaysia.

Li, J., Isayev, A.I., Ren, X. \& Soucek, M.D. 2016. Toward replacement of petroleum oils by modified soybean oils in elastomers. Rubber Chemistry and Technology 89(4): 608-630.

Liu, J., Li, X., Xu, L. \& Zhang, P. 2016. Investigation of aging behavior and mechanism of nitrile-butadiene rubber (NBR) in the accelerated thermal aging environment. Polymer Testing 54: 59-66.

Mostafa, A., Abouel-Kasem, A., Bayoumi, M.R. \& El-Sebaie, M.G. 2009. Effect of carbon black loading on the swelling and compression set behavior of SBR and NBR rubber compounds. Materials and Design 30(5): 1561-1568.

Nabil, H., Ismail, H. \& Azura, A.R. 2014. Optimisation of accelerators and vulcanising systems on thermal stability of natural rubber/recycled ethylene-propylene-dienemonomer blends. Materials and Design 53: 651-661.

Nandanan, V., Joseph, R. \& George, K.E. 1999. Rubber seed oil: A multipurpose additive in NR and SBR compounds. Journal of Applied Polymer Science 72(4): 487-492.

Pechurai, W., Chiangta, W. \& Tharuen, P. 2015. Effect of vegetable oils as processing aids in SBR compounds. Macromolecular Symposia 354(1): 191-196.

Petrović, Z.S., Milić, J., Ionescu, M. \& Halladay, J.R. 2017. Epdm rubber plasticized with polymeric soybean oil of different molecular weights. Rubber Chemistry and Technology 90(4): 667-682.

Petrović, Z.S., Ionescu, M., Milić, J. \& Halladay, J.R. 2013. Soybean oil plasticizers as replacement of petroleum oil in rubber. Rubber Chemistry and Technology 86(2): 233-249.

Rahmah, M., Wan Zain, N., Shafie, N.A. \& Norizan, M.N. 2013. Aromatic and epoxidised oil curing and rebound resilience characteristic and their humidity effect of hardness on NR vulcanizates. Advanced Materials Research 812(September): 138-144.

Raju, P., Nandanan, V. \& Kutty, S.K.N. 2007. A study on the use of castor oil as platicizer in natural rubber compounds. Progress in Rubber, Plastics and Recycling Technology 23(3): 169-180.

Rattanasom, N., Poonsuk, A. \& Makmoon, T. 2005. Effect of curing system on the mechanical properties and heat aging resistance of natural rubber/tire tread reclaimed rubber blends. Polymer Testing 24(6): 728-732.

Siwarote, B., Sae-oui, P., Wirasate, S. \& Suchiva, K. 2017. Effects of bio-based oils on processing properties and cure characteristics of silica-filled natural rubber compounds. Journal of Rubber Research 20(1): 1-19.

Surya, I., Ismail, H. \& Azura, A.R. 2015. The effect of alkanolamide loading on properties of carbon black-filled natural rubber (SMR-L), epoxidised natural rubber (ENR), and styrene-butadiene rubber (SBR) compounds. Polymer Testing 42: 208-214.

Surya, I., Ismail, H. \& Azura, A.R. 2013. Alkanolamide as an accelerator, filler-dispersant and a plasticizer in silica-filled natural rubber compounds. Polymer Testing 32(8): 13131321.

Wang, Z., Han, Y., Zhang, X., Huang, Z. \& Zhang, L. 2013. Plasticization effect of transgenic soybean oil. i. on ethylene propylene diene monomer (EPDM), as substitute for paraffin oil. Journal of Applied Polymer Science 130(6): 4457-4463. 
Wang, Z., Peng, Y., Zhang, L., Zhao, Y., Vyzhimov, R., Tan, T. \& Fong, H. 2016. Investigation of palm oil as green plasticizer on the processing and mechanical properties of ethylene propylene diene monomer rubber. Industrial and Engineering Chemistry Research 55(10): 2784-2789.

Department of Technology and Engineering Malaysian Rubber Board

RRIM station

47000 Sungai Buloh, Selangor Darul Ehsan

Malaysia
*Corresponding author; email: haniafiffa@1gm.gov.my

Received: 15 October 2019

Accepted: 12 May 2020 